Jurnal Ilmu Ilmu Agribisnis: Journal of Agribusiness Science, 9(3), Agustus 2021

\title{
ANALISIS EFISIENSI PRODUKSI DAN STRUKTUR BIAYA PADA USAHATANI NANAS DI DESA ASTOMULYO KECAMATAN PUNGGUR KABUPATEN LAMPUNG TENGAH
}

\author{
(Analysis of Production Efficiency and Cost Structure On Pineapple Farming In Astomulyo \\ Village Punggur Subdistrict Central Lampung Regency)
}

Aji Prayoga Wibowo, Wan Abbas Zakaria, Dyah Aring Hepiana Lestari

Jurusan Agribisnis, Fakultas Pertanian, Universitas Lampung, Jl. Prof. Dr. Soemantri Bojonegoro No.1

Bandar Lampung, 35145, e-mail : wan.abas@fp.unila.ac.id

\begin{abstract}
This study purposes to analyze factors that affect the production of pineapple farming, the production efficiency of pineapple farming, and the cost structure of pineapple farming. Data was collected at Astomulyo Village Punggur Subdistrict Central Lampung Regency from December 2019 - February 2020. The number of respondents was 63 farmers divided into 58 farmers who were members of farmer groups and the rest were non-members of farmer groups by using simple random sampling. The primary data had been obtained from a direct interview with the pineapple farmers and the second one had been obtained from several related studies and institutions. The data were analyzed using the Stochastic Frontier production function. The study shows the factors that affect the production of pineapple farming are land area, C/N ratio, $N$ element, and P element. Pineapple farming is technical, allocative, and economically efficient yet. The biggest cost of pineapple farming is costs of seed, land lease, and labor.
\end{abstract}

Key words: costs, efficiency, farmers, pineapple

\section{PENDAHULUAN}

Masyarakat Indonesia saat ini sudah banyak yang sadar akan pentingnya hidup sehat dengan meningkatkan konsumsi terhadap buah-buahan. Meningkatnya konsumsi buah-buahan menjadikan subsektor hortikultura menjadi subsektor yang memiliki prospek baik untuk diusahakan. Menurut Direktorat Jenderal Perkebunan (2018), dalam upaya peningkatan komoditas pertanian yang bernilai tambah, berdaya saing dalam memenuhi ekspor dan bersubtitusi impor periode 2015-2019, Kementerian Pertanian terfokus pada peningkatan 48 komoditas unggulan diantaranya adalah 8 komoditas hortikultura dan salah satunya adalah nanas.

Nanas merupakan buah yang menempati posisi ketiga dengan produksi dan volume ekspor tertinggi setelah pisang dan manggis. Menurut BPS (2018), Provinsi Lampung merupakan penghasil nanas terbesar di Indonesia. Tingkat produksi nanas tertinggi di Provinsi Lampung yaitu pada tahun 2017 sebanyak 633.095 ton atau 35,95 persen dari total produksi nanas di Indonesia. Sebagai penghasil nanas terbesar, perkembangan produksi nanas di Provinsi Lampung memiliki trend yang positif, pada tahun 2015-2018 produksi nanas cenderung mengalami peningkatan sebanyak
7,58 persen setiap tahunnya.

Sentra produksi nanas di Provinsi Lampung yaitu Kabupaten Lampung Tengah. Hampir seluruh produksi nanas di Provinsi Lampung dihasilkan Kabupaten Lampung Tengah. Produksi nanas pada tahun 2017 mencapai 632.338,50 ton atau 99,88 persen dari total produksi nanas di Provinsi Lampung (Kementerian Pertanian 2017). Terdapat dua pembudidaya nanas di Kabupaten Lampung Tengah yaitu perusahaan atau PT Great Giant Pineapple (GGP) dan rakyat. Hampir seluruh nanas yang dihasilkan oleh PT GGP adalah untuk komoditas ekspor, sedangkan untuk memenuhi kebutuhan nanas dalam negeri dapat dipenuhi melalui usahatani rakyat.

Kecamatan Punggur merupakan sentra produksi nanas yang dihasilkan oleh petani rakyat di Kabupaten Lampung Tengah. Nanas yang dibudidayakan yaitu nanas varietas Queen yang belum diminati pasar luar negeri. Sebagai sentra produksi nanas yang dibudidayakan oleh rakyat, perkembangan produksi nanas di Kecamatan Punggur memiliki trend yang negatif. Perkembangan produksi nanas pada tahun 2015 hingga 2017 cenderung mengalami penurunan dengan rata-rata penurunan 29.801,50 ton atau 11,02 persen per tahunnya (BPS Kabupaten 
Lampung Tengah 2017).

Desa Astomulyo merupakan desa penghasil nanas terbesar di Kecamatan Punggur. Perkembangan produksi nanas di Desa Astomulyo pada tahun 2015 hingga 2017 cenderung mengalami penurunan sebesar 1.789 ton atau 12,60 persen per tahunnya dan penurunan produktivitas sebesar 15,84 persen per tahunnya. Rata-rata produktivitas nanas di Desa Astomulyo sebesar 27,27 ton/ha, angka tersebut masih terbilang rendah berdasarkan data pada Agromedia (2016) yang menyatakan bahwa produktivitas nanas yang diusahakan secara intensif dapat mencapai 38-75 ton/ha. Rendahnya produktivitas ini diduga disebabkan karena penggunaan faktor produksi yang belum efisien dan terdapat masalah berupa penyakit yang menyerang tanaman nanas.

Jumlah penduduk Indonesia yang selalu meningkat akan menyebabkan permintaan terhadap nanas akan meningkat pula. Permintaan nanas yang meningkat akan mendorong petani nanas untuk meningkatkan produksinya. Namun, petani masih terkendala pada modal yang terbatas, lahan yang relatif sempit, teknologi yang masih sederhana, penggunaan sarana produksi yang belum tepat, dan juga adanya masalah berupa penyakit yang menyerang tanaman nanas. Kendala yang dihadapi petani menuntut mereka untuk meningkatkan efisiensi produksinya. Selain itu, tingginya biaya pupuk dalam kegiatan produksi akan menimbulkan biaya variabel yang tinggi sehingga pendapatan yang diterima petani secara tunai semakin rendah.

Berdasarkan uraian pendahuluan, maka tujuan penelitian ini antara lain untuk mengetahui faktorfaktor yang mempengaruhi produksi nanas, menganalisis efisiensi teknis, alokatif, dan ekonomis usahatani nanas, dan mengetahui struktur biaya usahatani nanas.

\section{METODE PENELITIAN}

Penelitian dilakukan di Desa Astomulyo Kecamatan Punggur Kabupaten Lampung Tengah dengan menggunakan metode penelitian survei. Penentuan lokasi penelitian dilakukan secara sengaja (purposive) dengan pertimbangan bahwa Kecamatan Punggur merupakan sentra produksi nanas yang diusahakan oleh rakyat.

Jenis data yang digunakan adalah data primer dan data sekunder. Pengambilan data dilakukan di Desa Astomulyo dengan pertimbangan bahwa desa tersebut merupakan sentra produksi nanas dengan tingkat produksi terbesar di Kecamatan Punggur. Data primer yang diambil hanya pada satu musim tanam hingga musim panen pertama dengan pertimbangan bahwa akan lebih mudah dalam memperoleh informasi terkait penggunaan input dan produksi yang dihasilkan. Pengambilan data dilaksanakan pada November 2019 sampai Februari 2020.

Populasi pada penelitian ini adalah petani nanas berjumlah 362 petani. Jumlah sampel penelitian diambil dengan mengacu pada Isaac dan Michael dalam Sugiarto, Sunaryanto, dan Oetomo (2003) dengan persamaan :

$\mathrm{n}=\frac{\mathrm{NZ}^{2} \mathrm{~s}^{2}}{\mathrm{ND}^{2}+\mathrm{Z}^{2} \mathrm{~s}^{2}}$

Keterangan :

$\mathrm{n} \quad=$ Jumlah sampel

$\mathrm{N}=$ Jumlah populasi petani (362)

$\mathrm{Z}=$ Tingkat kepercayaan $(95 \%=1,96)$

$\mathrm{S}^{2}=$ Varian sampel $(5 \%)$

$\mathrm{D}=$ Derajat penyimpangan $(5 \%)$

Berdasarkan persamaan 1, jumlah sampel yang diperoleh adalah 63 orang, selanjutnya dihitung proporsi sampel petani yang tergabung dan tidak tergabung dengan kelompoktani dengan menggunakan rumus :

$\mathrm{n}_{\mathrm{i}}=\frac{\mathrm{N}_{\mathrm{i}}}{\mathrm{N}} \times \mathrm{n}$

Keterangan :

ni $=$ jumlah sampel petani nanas di setiap kelompok

$\mathrm{Ni}=$ jumlah petani nanas di setiap kelompok

$\mathrm{N}=$ jumlah keseluruhan populasi petani

$\mathrm{n} \quad=$ jumlah keseluruhan sampel petani

Berdasarkan perhitungan, diperoleh sampel untuk petani yang tergabung dalam kelompoktani sebanyak 58 petani dan yang tidak tergabung dalam kelompoktani sebanyak 5 petani. Pengambilan sampel dilakukan secara acak sederhana (simple random sampling).

Analisis fungsi produksi Stochastic Frontier digunakan untuk mengetahui pengaruh penggunaan faktor produksi terhadap produksi nanas yang dihasilkan. Mengacu pada Coelli dan Battese dalam Nurjati, Fahmi, Jahroh (2018), untuk mempermudah pendugaan fungsi produksi nanas, persamaan regresi Stochastic Frontier diubah dalam bentuk linier berganda dengan cara pendekatan logaritma menjadi persamaan 3 . 
$\begin{aligned} \ln \mathrm{Y}= & \beta_{0}+\beta_{1} \ln \mathrm{X}_{1}+\beta_{2} \ln \mathrm{X}_{2}+\beta_{3} \ln \mathrm{X}_{3}+\beta_{4} \ln \mathrm{X}_{4}+\beta_{5} \ln \mathrm{X}_{5}+\beta_{6} 1 \\ & \mathrm{nX} \mathrm{X}_{6}+\beta_{7} \ln \mathrm{X}_{7}+\beta_{8} \ln \mathrm{X}_{8}+\mathrm{v}_{\mathrm{i}} \mathrm{u}_{\mathrm{i}} \ldots \ldots \ldots \ldots \ldots \ldots \ldots \ldots . . . \ldots \ldots \ldots \ldots \ldots \ldots \ldots \ldots\end{aligned}$

Keterangan :

$Y \quad=$ jumlah total produksi nanas $(\mathrm{kg})$

$\mathrm{X}_{1}=$ luas lahan (ha)

$\mathrm{X}_{2}=$ bibit (batang)

$\mathrm{X}_{3}=$ nisbah $\mathrm{C} / \mathrm{N}(\mathrm{kg})$

$\mathrm{X}_{4}=\operatorname{unsur} \mathrm{N}(\mathrm{kg})$

$\mathrm{X}_{5}=$ unsur $\mathrm{P}(\mathrm{kg})$

$\mathrm{X}_{6}=$ unsur $\mathrm{K}(\mathrm{kg})$

$\mathrm{X}_{7}=$ herbisida $(\mathrm{gba})$

$\mathrm{X}_{8}=$ tenaga kerja $(\mathrm{HOK})$

$\beta_{0}=$ intersep

$\beta=$ parameter yang diestimasi

$v_{i}-u_{i}=$ error term (vi kesalahan pengganggu, $u i$ efek inefesiensi teknis dalam model)

Pengukuran tingkat efisiensi (TE) teknis mengacu pada rumus Coelli dan Battese (1998) dalam persamaan :

$\mathrm{TE}=\mathrm{E}[\exp \exp (\varepsilon)]$

Metode inefisiensi teknis yang digunakan pada penelitian ini mengacu pada model inefisiensi teknis yang dikembangkan oleh Coelli dan Battese dalam Ambarita, Prasmatiwi, dan Nugraha (2014). Variabel $u_{i}$ yang digunakan untuk mengukur efek inefisiensi teknis, diasumsikan bebas dan distribusinya terpotong normal. Untuk menentukan nilai parameter distribusi $\left(u_{i}\right)$ efek inefisiensi teknis pada penelitian ini digunakan persamaan :

$\mathrm{u}_{\mathrm{i}}=\alpha_{0}+\alpha_{1} \mathrm{Z}_{1}+\alpha_{2} \mathrm{Z}_{2}+\alpha_{3} \mathrm{Z}_{3}+\alpha_{4} \mathrm{Z}_{4}+\alpha_{5} \mathrm{Z}_{5}+\alpha_{6} \mathrm{D}_{1}$

Keterangan :

$\mu i=$ efek inefesiensi teknis

$\mathrm{Z}_{1}=$ umur petani (tahun)

$\mathrm{Z}_{2}=$ pengalaman bertani (tahun)

$\mathrm{Z}_{3}=$ pendidikan formal petani (tahun)

$\mathrm{Z}_{4}=$ jumlah tanggungan anggota keluarga petani (orang)

$\mathrm{Z}_{5}=$ jumlah tanaman terserang penyakit (tanaman)

$\mathrm{D}_{1}=$ dummy keikutsertaan kelompoktani $(d=1$ untuk ikut kelompoktani; $d=0$ untuk tidak ikut kelompoktani)

Setelah dilakukan analisis regresi dan efisiensi teknis, selanjutnya dilakukan analisis efisiensi ekonomi dengan persamaan :

$\mathrm{EE}=\frac{\mathrm{Ci}}{\mathrm{Ci}^{*}}=\frac{\mathrm{E}\left(\mathrm{Ci} \mid \mathrm{Ui}=0, \mathrm{Yi}_{i}, \mathrm{Pi}\right)}{\mathrm{E}\left(\mathrm{Yi} \mid \mathrm{Ui}, \mathrm{Yi}_{\mathrm{Pi}}\right)}$
Keterangan :

$\mathrm{EE}=$ efisiensi ekonomis

$\mathrm{C}_{\mathrm{i}}=$ rasio total biaya produksi minimum yang diobservasi

$\mathrm{C}_{\mathrm{i}}^{*}=$ total biaya produksi aktual secara keseluruhan

$\mathrm{C}_{\mathrm{i}}^{*}$ merupakan fungsi biaya dual yang diperoleh dari fungsi produksi Stochastic Frontier dan fungsi biaya input sehingga diperoleh fungsi biaya dual dengan persamaan :

$\mathrm{C}_{\mathrm{i}}^{*}=\mathrm{f}\left(\mathrm{Y}_{3} \mathrm{P}_{1}, \mathrm{P}_{2}, \mathrm{P}_{3}, \mathrm{P}_{4}, \mathrm{P}_{5}, \mathrm{P}_{6}, \mathrm{P}_{7}, \mathrm{P}_{8}, \mathrm{P}_{9}\right)$.

$\mathrm{Y}$ adalah hasil produksi nanas, dan $\mathrm{P}_{1}-\mathrm{P}_{9}$ berturutturut adalah harga sewa lahan, harga bibit, harga pupuk kandang, harga pupuk Urea, harga pupuk NPK Mutiara, harga pupuk NPK Phonska, harga pupuk SP-36, harga herbisida, dan upah tenaga kerja.

Efisiensi ekonomis diperoleh dari efisiensi teknis dan efisiensi alokatif, sehingga efisiensi alokatif (AE) ditulis dengan persamaan :

$\mathrm{AE}=\frac{\mathrm{EE}}{\mathrm{TE}}$.

Menurut Coelli dan Battese (1998) suatu usahatani dikatakan sangat efisien jika TE, EE, dan $\mathrm{AE} \geq$ 0,90; cukup efisien jika $0,70 \leq \mathrm{TE}, \mathrm{EE}$, dan $\mathrm{AE} \leq$ 0,90; dan belum efisien jika $\mathrm{TE}, \mathrm{EE}$, dan $\mathrm{AE} \leq$ 0,70 .

Menurut Sumodiningrat dan Iswara dalam Misgiantoro, Prasmatiwi, dan Nurmayasari (2016), analisis struktur biaya digunakan untuk mengetahui persentase setiap biaya yang dikeluarkan dalam usahatani nanas. Untuk menghitung total biaya dalam usahatani digunakan persamaan :

$\mathrm{TC}=\mathrm{TFC}+\mathrm{TVC}$

Keterangan :

TFC = total biaya tetap (Rp)

$\mathrm{TVC}=$ total biaya variabel $(\mathrm{Rp})$

Setelah dilakukan perhitungan biaya total, dapat dilakukan perhitungan untuk mengetahui pendapatan dengan mengurangi penerimaan dengan biaya totalnya. Untuk mengetahui apakah usahatani nanas menguntungkan atau tidak dapat dilanjutkan dengan menghitung rasio antara penerimaan dengan biaya atau R/C. Untuk mencari persentase dari setiap biaya digunakan persamaan 10. 
Jurnal Ilmu Ilmu Agribisnis: Journal of Agribusiness Science, 9(3), Agustus 2021

Tabel 1. Penggunaan sarana produksi pada usahatani nanas (per ha)

\begin{tabular}{lrr}
\hline \multicolumn{1}{c}{ Sarana Produksi } & Penggunaan & Anjuran \\
\hline Bibit (batang) & 38.617 & $38.000-40.000$ \\
Pupuk kandang (kg) & $7.442,57$ & $10.000-15.000$ \\
Pupuk Urea (kg) & 675,97 & $450-600$ \\
Pupuk NPK Phonska (kg) & 231,26 & $100-200$ \\
Pupuk SP-36 (kg) & 231,26 & $60-75$ \\
Pupuk NPK Mutiara(kg) & 101,60 & $50-100$ \\
Tenaga kerja (HOK) & 218,27 & \\
\hline
\end{tabular}

$\mathrm{P}=\frac{\text { NTFCxNTVC }}{\mathrm{NTC}} \times 100 \%$

Keterangan :

$\mathrm{P} \quad=$ Persentase dari struktur biaya produksi $(\%)$

NTFC $=$ Nilai dari tiap komponen biaya tetap (Rp)

NTVC $=$ Nilai dari tiap komponen biaya variabel (Rp)

NTC $=$ Nilai dari total biaya produksi $(\mathrm{Rp})$

\section{HASIL DAN PEMBAHASAN}

\section{Keadaan Umum Responden}

Sebanyak 53,97 persen petani berada pada kelompok umur 38 - 49 tahun dan 44,44 persen petani menempuh tingkat pendidikan hingga jenjang sekolah dasar (SD). Mayoritas petani nanas memiliki jumlah tanggungan keluarga sebanyak $3-4$ orang $(63,49 \%)$ dan memiliki pengalaman berusahatani nanas antara $11-15$ tahun $(42,86 \%)$.

Rata-rata luas lahan yang digunakan petani untuk menanam nanas adalah 0,74 ha dengan status kepemilikan lahan yang seluruhnya merupakan lahan milik sendiri. Hampir seluruh petani atau sebanyak 96,83 persen memiliki persepsi bahwa usahatani nanas masih memiliki prospek yang baik untuk dijalankan, sedangkan sisanya 3,17 persen sudah mulai mengganti dengan tanaman lain dikarenakan risiko yang dihadapi tergolong tinggi.

Budidaya nanas di Desa Astomulyo menggunakan pola tanam satu alur dengan jarak tanam $25 \times 100$ $\mathrm{cm}$. Penanaman dilakukan pada awal musim penghujan untuk mempercepat pengakaran karena tidak adanya saluran irigasi. Jenis bibit yang digunakan yaitu bibit sogolan yang berasal dari anak tanaman. Tabel 1 menunjukkan bahwa penggunaan sarana produksi di lokasi penelitian sudah sesuai atau bahkan ada yang melebihi anjuran menurut Balai Penelitian Tanaman Buah

Tropika (2008) seperti penggunaan bibit dan pupuk kimia, sedangkan untuk penggunaan pupuk kandang belum sesuai dengan anjuran penggunaan.

Golongan obat-obatan yang digunakan yaitu herbisida karena fokus pengendalian organisme pengganggu tanaman (OPT) yaitu pada pengendalian gulma. Peralatan usahatani yang digunakan petani nanas terdiri dari cangkul, arit, dan handsprayer. Hasil rata-rata produksi nanas di Desa Astomulyo sebanyak 24.048 buah/0,74 ha atau 32.406 buah/ha dengan harga jual rata-rata Rp3.237,00/buah untuk grade A, Rp2.171,00/buah untuk grade $\mathrm{B}$ dan $\mathrm{Rp} 1.537,00 / \mathrm{buah}$ untuk grade C.

\section{Faktor-faktor yang Mempengaruhi Produksi Nanas}

Faktor-faktor yang mempengaruhi produksi nanas diuraikan berdasarkan hasil yang diperoleh dari analisis fungsi produksi Stochastic Frontier.

Koefisien regresi fungsi produksi menggunakan 8 variabel dengan pendugaan paramater dengan menggunakan program FRONTIER 4.1.

Hasil pendugaan (Tabel 2) menunjukkan nilai $\log$ likelihood dengan metode Maximum Likelihood Estimated (MLE) sebesar 153,44 yang lebih besar dari nilai log likelihood dengan metode OLS sebesar 140,44 yang berarti fungsi produksi metode MLE ini adalah baik dan sesuai dengan kondisi lapangan. Nilai sigma-squared $(\sigma)$ dan gamma $(\gamma)$ yang diperoleh dari pendugaan dengan metode MLE adalah sebesar 0,0006 dan 0,5593 pada tingkat kepercayaan 99 persen. Nilai $\sigma$ yang lebih besar dari 0 menunjukkan adanya pengaruh dari technical efficiency dalam model. Coelli dan Battese dalam Noer, Zakaria, dan Murniati (2018) menyatakan bahwa apabila nilai $\sigma=0$ maka tidak terdapat pengaruh dari technical efficiency.

Nilai $\gamma$ menunjukkan bahwa variasi nilai komposit eror disebabkan oleh komponen technical efficiency yaitu sebesar 0,5593. Hal ini menunjukkan bahwa adanya senjang produksi yang disebabkan oleh efek inefisiensi teknis, bukan 
Jurnal Ilmu Ilmu Agribisnis: Journal of Agribusiness Science, 9(3), Agustus 2021

Tabel 2. Hasil pendugaan fungsi produksi Stochastic Frontier nanas di Desa Astomulyo Kecamatan Punggur Kabupaten Lampung Tengah

\begin{tabular}{|c|c|c|c|}
\hline Variabel & Koefisien & Std Eror & t-ratio \\
\hline Intersep $(\alpha)$ & $12,0260^{\mathrm{a}}$ & 3,0683 & 3,9194 \\
\hline Luas lahan $\left(\mathrm{X}_{1}\right)$ & $1,2469^{\mathrm{a}}$ & 0,2896 & 4,3059 \\
\hline Bibit $\left(\mathrm{X}_{2}\right)$ & 0,0051 & 0,3251 & 0,0156 \\
\hline Unsur $\mathrm{C} / \mathrm{N}\left(\mathrm{X}_{3}\right)$ & $-0,3258^{\mathrm{a}}$ & 0,0767 & $-4,2496$ \\
\hline Unsur N ( $\left.\mathrm{X}_{4}\right)$ & $0,3006^{\mathrm{b}}$ & 0,1429 & 2,1044 \\
\hline Unsur P $\left(\mathrm{X}_{5}\right)$ & $-0,2093^{\mathrm{a}}$ & 0,0732 & $-2,8607$ \\
\hline Unsur $\mathrm{K}\left(\mathrm{X}_{6}\right)$ & 0,0728 & 0,0671 & 1,0839 \\
\hline Herbisida $\left(\mathrm{X}_{7}\right)$ & 0,0056 & 0,0076 & 0,7352 \\
\hline Tenaga kerja $\left(\mathrm{X}_{8}\right)$ & $-0,0638$ & 0,0687 & $-0,9276$ \\
\hline Sigma-squared ( $\sigma$ ) & $0,0006^{\mathrm{a}}$ & 0,0002 & 4,0747 \\
\hline $\operatorname{Gamma}(\gamma)$ & $0,5593^{\mathrm{a}}$ & 0,0909 & 6,5938 \\
\hline Log likelihood OLS & & & 140,3755 \\
\hline Log likelihood MLE & & & 152,3945 \\
\hline LR-test & & & 24,0379 \\
\hline
\end{tabular}

Keterangan : $a, b$, dan c signifikan pada $\alpha=0,01 ; 0,05$; dan 0,1

oleh faktor eror yang merupakan faktor lain yang tidak terdapat di dalam model.

Lebih lanjut, Tabel 2 menunjukkan bahwa luas lahan, nisbah $\mathrm{C} / \mathrm{N}$, dan unsur $\mathrm{P}$ berpengaruh pada produksi nanas dengan tingkat kepercayaan 99 persen; unsur $\mathrm{N}$ berpengaruh terhadap produksi nanas dengan tingkat kepercayaan 95 persen; sedangkan bibit, unsur $\mathrm{K}$, herbisida, dan tenaga kerja tidak berpengaruh nyata terhadap produksi nanas.

Nisbah $\mathrm{C} / \mathrm{N}$ berkorelasi negatif terhadap produksi nanas dikarenakan penggunaan pupuk kandang yang masih mentah yang merupakan sumber utama nisbah $\mathrm{C} / \mathrm{N}$ yang tinggi. Unsur $\mathrm{P}$ berkorelasi negatif terhadap produksi nanas karena penggunaan pupuk SP-36 yang berlebih dan merupakan sumber unsur $\mathrm{P}$ tertinggi.

\section{Analisis Efisiensi dan Inefisiensi Teknis}

Efisiensi teknis dianalisis dengan menggunakan model fungsi produksi Stochastic Frontier melalui pendekatan dari sisi output.

Tabel 3. Sebaran efisiensi teknis usahatani nanas di Desa Astomulyo Kecamatan Punggur Kabupaten Lampung Tengah

\begin{tabular}{lcc}
\hline Efisiensi Teknis & $\begin{array}{c}\text { Jumlah } \\
\text { (Orang) }\end{array}$ & Persentase (\%) \\
\hline$<0,90$ & 2 & 3,17 \\
$\geq 0,90$ & 61 & 96,83 \\
\hline Jumlah & 63 & 100,00 \\
Rata-rata & 0,9803 & \\
Minimum & 0,8915 & \\
Maksimum & 0,9983 & \\
\hline
\end{tabular}

Kategori efisiensi teknis pada penelitian mengacu pada Coelli dan Battese (1998) yaitu sangat efisien jika nilai $\mathrm{ET} \geq 0,90$, cukup efisien jika nilai ET antar 0,70 dan 0,90, dan belum efisien jika nilai ET $<0,70$. Tabel 3 menunjukkan bahwa sebanyak 61 petani atau 96,83 persen petani nanas memiliki nilai efisiensi teknis $\geq 0,90$, dan 2 petani atau 3,17 persen $<0,90$. Rata-rata nilai efisiensi teknis petani di Desa Astomulyo sebesar 0,98 yang berarti petani nanas sudah menjalankan usahataninya dengan sangat efisien. Nilai rata-rata efisiensi teknis dalam penelitian ini lebih besar jika dibandingkan dengan penelitian Silaban, Ginting, dan Jufri (2017) yang memperoleh nilai efisiensi teknis usahatani nanas di Desa Siabal-abal 2 Kecamatan Sipahutar Kabupaten Tapanuli Utara sebesar 0,90

Tingkat efisiensi teknis dapat diinterpretasikan berwajah ganda. Di satu sisi, tingkat efisiensi yang tinggi mencerminkan prestasi petani dalam keterampilan manajerial yang cukup tinggi. Sisi lain, tingkat efisiensi yang tinggi merefleksikan bahwa peluang untuk meningkatkan produktivitas yang cukup tinggi semakin kecil, karena senjang antara tingkat produktivitas maksimum yang dapat dicapai dengan sistem pengolahan terbaik cukup sempit (Sumaryanto 2003). Sumber-sumber inefisiensi teknis diperoleh dari hasil pendugaan model fungsi produksi Stochastic Frontier. Tabel 4 menunjukkan bahwa variabel jumlah tanaman terserang penyakit berpengaruh nyata pada tingkat kepercayaan 99 persen terhadap inefisiensi teknis usahatani nanas, variabel umur, pengalaman, jumlah tanggungan anggota keluarga, dan dummy keikutsertaan kelompoktani berpengaruh nyata walaupun hanya dengan tingkat kepercayaan 80 persen terhadap inefisiensi teknis usahatani nanas, 
Tabel 4. Hasil pendugaan faktor inefisiensi teknis usahatani nanas di Desa Astomulyo Kecamatan Punggur Kabupaten Lampung Tengah

\begin{tabular}{lccr}
\hline \multicolumn{1}{c}{ Variabel } & Koefisien & Std. Eror & t-rasio \\
\hline Intersep $(\delta)$ & $13,0260^{\mathrm{a}}$ & 3,0683 & 3,9194 \\
Umur Petani $\left(\mathrm{Z}_{1}\right)$ & $-0,0458^{\mathrm{c}}$ & 0,0286 & $-1,5998$ \\
Pengalaman $\left(\mathrm{Z}_{2}\right)$ & $-0,0414^{\mathrm{c}}$ & 0,0291 & $-1,4230$ \\
Pendidikan $\left(\mathrm{Z}_{3}\right)$ & $-0,0052$ & 0,0200 & $-0,2628$ \\
Jumlah Tanggungan $\left(\mathrm{Z}_{4}\right)$ & $0,0141^{\mathrm{c}}$ & 0,0101 & 1,3172 \\
Tanaman terserang penyakit $\left(\mathrm{Z}_{5}\right)$ & $0,0707^{\mathrm{a}}$ & 0,0147 & 4,8223 \\
Dummy kelompoktani $\left(\mathrm{D}_{1}\right)$ & $-0,0338^{\mathrm{c}}$ & 0,0199 & $-1,6965$ \\
\hline
\end{tabular}

sedangkan variabel pendidikan tidak berpengaruh nyata terhadap inefisiensi teknis usahatani nanas.

Variabel umur dan variabel pengalaman berusahatani memiliki koefisien negatif dan berpengaruh nyata, hal tersebut menunjukkan bahwa semakin tua umur petani dan semakin lama pengalamannya berusahatani maka akan menurunkan tingkat inefisiensi teknis, hasil ini sejalan dengan penelitian Rofiqoh, Agustina, dan Hartadi (2018) yang menyatakan bahwa umur dan pengalaman berusahatani pada usahatani semangka di Desa Mayangan Kecamatan Gumukmas Kabupaten Jember berpengaruh negatif dan berpengaruh nyata terhadap inefisiensi usahatani semangka atau dapat meningkatkan efisiensi teknis usahatani semangka.

Hasil ini juga sejalan dengan penelitian Estariza, Prasmatiwi, dan Santoso (2013) yang menyatakan bahwa umur dan pengalaman berusahatani dapat meningkatkan tingkat efisiensi teknis. Variabel jumlah tanggungan keluarga menunjukkan bahwa semakin banyak jumlah tanggungan keluarga petani akan meningkatkan tingkat inefisiensi teknis usahatani nanas. Hal ini dikarenakan rata-rata anggota keluarga petani yang berada pada umur belum produktif yaitu pada kelompok umur kurang dari 15 tahun (Mantra 2004) yang akan meningkatkan pengeluaran untuk rumah tangga petani sehingga akan mengurangi pengeluaran untuk usahataninya.

Variabel jumlah tanaman yang terserang penyakit menunjukkan bahwa semakin banyak jumlah tanaman yang terserang penyakit akan meningkatkan tingkat inefisiensi teknis usahatani nanas. Dummy kelompoktani menunjukkan bahwa petani yang tergabung dalam kelompoktani dapat menurunkan tingkat inefisiensi teknis karena dapat memperoleh kebutuhan pupuk tepat waktu.

\section{Analisis Efisiensi Alokatif dan Efisiensi Ekonomis}

Efisiensi ekonomis merupakan efek gabungan dari efisiensi teknis dan efisiensi alokatif sehingga usahatani dapat dikatakan efisien secara ekonomis jika efisiensi teknis dan efisiensi alokatifnya sudah tercapai. Sebaran efisiensi alokatif dan efisiensi ekonomis dianalisis dari harga input yang berlaku. Nilai efisiensi teknis (EE) dihitung dari satu dibagi nilai efisiensi biaya setiap petani, dan efisiensi alokatif diperoleh dari membagi efisiensi ekonomis dengan efisiensi teknis. Sebaran efisiensi alokatif dan efisiensi ekonomis usahatani nanas disajikan pada Tabel 5.

Tabel 5 menunjukkan hasil sebaran nilai efisiensi alokatif dan ekonomis usahatani nanas seluruh responden memiliki nilai $\geq 0,90$ yang berarti bahwa usahatani nanas sudah sangat efisien secara alokatif dan ekonomis. Rata-rata efisiensi alokatif petani nanas sebesar 1,02, yang menunjukkan bahwa besarnya produksi marjinal dapat melebihi biaya keluaran marjinal dari setiap input yang dikeluarkan. Rata-rata nilai efisiensi ekonomis petani nanas sebesar 0,99 yang berarti keuntungan mayoritas petani sudah mencapai maksimum karena inefisiensi ekonomis yang terjadi hanya sebesar 0,28 persen. Nilai tersebut lebih besar jika dibandingkan dengan penelitian Lubis et.al. (2014) yang menyatakan bahwa rata-rata nilai efisiensi alokatif dan ekonomis usahatani nanas di Kabupaten Subang Provinsi Jawa Barat sebesar 0,74 dan 0,41 atau dengan kata lain dalam kategori cukup efisien secara alokatif dan belum efisien secara ekonomis.

\section{Analisis Struktur Biaya Usahatani Nanas}

Tabel 6 menunjukkan rata-rata penerimaan usahatani nanas sebesar Rp76.842.662,82/ha, 
Jurnal Ilmu Ilmu Agribisnis: Journal of Agribusiness Science, 9(3), Agustus 2021

Tabel 5. Sebaran efisiensi alokatif dan ekonomis usahatani nanas di Desa Astomulyo Kecamatan Punggur Lampung Tengah

\begin{tabular}{|c|c|c|c|c|}
\hline \multirow{2}{*}{ Tingkat Efisiensi } & \multicolumn{2}{|c|}{ Efisiensi Alokatif } & \multicolumn{2}{|c|}{ Efisinsi Ekonomis } \\
\hline & Jumlah & Persentase & Jumlah & Persentase \\
\hline$\geq 0,90$ & 63 & 100 & 63 & 100 \\
\hline Jumlah & 63 & 100 & 63 & 100 \\
\hline Rata-rata & & & & \\
\hline Minimum & & & & \\
\hline Maksimum & & & & \\
\hline
\end{tabular}

sedangkan biaya total yang dikeluarkan sebesar Rp42.470.595,12/ha. Pendapatan usahatani nanas yang diperoleh sebesar Rp34.372.067,69/ha. Nilai $\mathrm{R} / \mathrm{C}$ yang diperoleh sebesar 1,81 yang berarti usahatani nanas menguntungkan untuk diusahakan. Hal ini sejalan dengan penelitian Agus, Rangga, dan Viantimala (2017) yang menunjukkan bahwa usahatani nanas di Astomulyo Kecamatan Punggur Kabupaten Lampung Tengah memiliki nilai R/C > 1 sehingga menguntungkan untuk diusahakan.

Struktur biaya usahatani nanas terbagi atas biaya tetap dan biaya variabel. Total biaya variabel memberikan kontribusi yang lebih tinggi dibandingkan biaya tetap terhadap biaya total. Total biaya variabel pada usahatani nanas sebesar Rp33.632.260,99/ha atau sebesar 79,19 persen, sedangkan biaya tetap sebesar Rp8.838.334,14/ha atau sebesar 20,81 persen. Tingginya biaya yang dikeluarkan memerlukan manajemen biaya yang tepat agar usahatani yang dijalankan tidak menimbulkan biaya yang berlebih.

Komponen biaya tertinggi yang dikeluarkan petani yaitu biaya bibit, biaya sewa lahan, dan biaya tenaga kerja dengan persentase sebesar 45,59 persen, 20,17 persen, dan 17,96 persen terhadap biaya total. Hasil ini sejalan dengan penelitian Roza, Yulida dan Yusri (2015) yang menyatakan bahwa ketiga komponen biaya terbesar pada usahatani nanas di Desa Kualu Nenas Kecamatan Tambang Kabupaten Kampar yaitu biaya tenaga kerja, biaya bibit, dan biaya sewa sebesar 49,39 persen, 37,25 persen, dan 6,67 persen. Besarnya ketiga komponen biaya tersebut sudah diminimalisir petani dengan cara penggunaan bibit yang berasal dari lahan sendiri, penggunaan tenaga kerja dalam keluarga, dan penggunaan lahan milik sendiri.

\section{KESIMPULAN}

Faktor-faktor yang mempengaruhi produksi nanas yaitu luas lahan, nisbah $\mathrm{C} / \mathrm{N} \mathrm{C} / \mathrm{N}$, unsur $\mathrm{N}$, dan unsur P. Usahatani nanas di Desa Astomulyo Kecamatan Punggur Kabupaten Lampung Tengah sudah sangat efisien secara teknis, alokatif, dan ekonomis. Komponen biaya terbesar pada usahatani nanas yaitu biaya bibit, biaya tenaga kerja, dan biaya sewa lahan.

Tabel 6. Analisis struktur biaya usahatani nanas di Desa Astomulyo Kecamatan Punggur Kabupaten Lampung Tengah

\begin{tabular}{clrr}
\hline No & & Traian & Persentase Biaya (\%) \\
\hline 1 & Penerimaan & $76.842 .662,82$ & \\
& Nanas Grade A & $37.509 .335,87$ & \\
& Nanas Grade B & $24.660 .368,28$ & 20,81 \\
& Nanas Grade C & $14.672 .958,66$ & 0,48 \\
& Biaya Tetap & $8.838 .334,14$ & 20,17 \\
& Peny. Alat & $203.636,58$ & 0,17 \\
& Sewa Lahan & $8.564 .287,86$ & 79,19 \\
& Pajak & $70.409,70$ & 45,59 \\
& Biaya Variabel & $33.632 .260,99$ & 6,59 \\
& Bibit & $19.362 .398,11$ & 8,14 \\
& Pupuk Kandang & $2.798 .745,17$ & 0,89 \\
& Pupuk Kimia & $3.455 .436,54$ & 17,98 \\
\hline & Obat-Obatan & $377.435,77$ & 100 \\
\hline
\end{tabular}




\section{DAFTAR PUSTAKA}

Agromedia. 2016. Budi Daya Tanaman Buah Unggul Indonesia. Redaksi Agromedia. Jakarta.

Agus GV, Rangga K., Viantimala B. 2017. Kinerja dan pendapatan rumah tangga anggota kelompoktani nanas di Desa Astomulyo Kecamatan Punggur Kabupaten Lampung Tengah. Jurnal Ilmu Ilmu Agribisnis, 5 (1): 84-92.

https://jurnal.fp.unila.ac.id/index.php/Jurnal Ilmu Ilmu Agribisnis/article/view/1678/1504. [20 Mei 2020].

Ambarita MM, Prasmatiwi FE, Nugraha A. 2014. Analisis efisiensi produksi frontier dan pendapatan usahatani kedelai Sekolah Lapangan Pengelolaan Tanaman Terpadu (SL-PPT) di Kabupaten Lampung Selatan. 2014. Jurnal Ilmu Ilmu Agribisnis, 2 (4): 348355.

https://jurnal.fp.unila.ac.id/index.php/Jurnal

Ilmu Ilmu Agribisnis/article/view/989/895. [15 Mei 2020].

BPS [Badan Pusat Statistik]. 2018. Tabel Dinamis Produksi Tanaman Nanas. https://bps.go.id. [25 Juli 2019].

BPS [Badan Pusat Statistik] Kabupaten Lampung Tengah. 2017. Kabupaten Lampung Tengah Dalam Angka. https://lampungtengahkab.bps.go.id. [25 Juli 2019].

Balai Penelitian Tanaman Buah Tropika. 2008. Budidaya Nenas. Balai Penelitian Tanaman Buah Tropika. Sumatera Barat.

Coelli T and Battese GE. 1998. An Introduction to Efficiency and Productivity Analysis. Kluwer Academic Publishers. Boston.

Direktorat Jenderal Perkebunan. 2018. Rencana Strategis Direktorat Jenderal Perkebunan Tahun 2015-2019 (Edisi Revisi Ke-3). http://ditjenbun.pertanian.go.id/infopublik/ren cana-strategis/. [25 Juli 2019].

Estariza E, Prasmatiwi FE, Santoso H. 2013. Efisiensi produksi dan pendapatan usahatani tembakau di Kabupaten Lampung Timur. Jurnal Ilmu Ilmu Agribisnis, 1 (3): 264-270. https://jurnal.fp.unila.ac.id/index.php/Jurnal Ilmu Ilmu Agribisnis/article/view/582/544. [6 Mei 2020].

Kementerian Pertanian. 2017. Produksi Nanas Berdasarkan Kabupaten / Kota. https://apliaksi2.pertanian.go.id/. [25 Juli 2019].

Lubis RRB, Daryanto A, Tambunan M, Rachman HPS. 2014. Analisis efisiensi teknis, produksi nanas : studi kasus di Kabupaten
Subang, Jawa Barat. Jurnal Agro Ekonomi, 32 (2): 91-106. http://ejurnal.litbang.pertanian.go.id/index.ph p/jae/article/view/3987/3322. [20 Mei 2020].

Mantra IB. 2004. Demografi Umum. Pustaka Pelajar. Yogyakarta.

Misgiantoro R, Prasmatiwi FE, Nurmayasari I. 2016. Analisis efisiensi produksi dan pendapatan usahatani jahe gajah di Kecamatan Penengahan Kabupaten Lampung Selatan. Jurnal Ilmu Ilmu Agribisnis, 5 (1): 22-30.

https://Jurnal.Fp.Unila.Ac.Id/Index.Php/JURN AL ILMU ILMU AGRIBISNIS/article/view/1671/1497. [5 Mei 2020].

Noer SR, Zakaria WA, Murniati K. 2018. Analisis efisiensi produksi usahatani padi ladang di Kecamatan Sidomulyo Kabupaten Lampung Selatan. Jurnal Ilmu Ilmu $\begin{array}{llll}\text { Agribisnis, } & 6 & \text { (1): }\end{array}$ https://jurnal.fp.unila.ac.id/index.php/Jurnal Ilmu Ilmu Agribisnis/article/view/2492/2178. [5 Mei 2020].

Nurjati E, Fahmi I, Jahroh S. 2018. Analisis efisiensi produksi bawang merah di Kabupaten Pati dengan fungsi produksi frontier stokastik Cobb-Douglas. Jurnal Agro $\begin{array}{llll}\text { Ekonomi, } & 36 & \text { (1): } & \text { 55-69. }\end{array}$ http://ejurnal.litbang.pertanian.go.id/index.ph p/jae/article/view/8343/8050. [5 Mei 2020]. Rofiqoh L, Agustina T, Hartadi R.2018. Analisis efisiensi teknis penggunaan faktorfaktor produksi usahatani semangka di Desa Mayangan Kecamatan Gumukmas Kabupaten Jember. Jurnal Agribest, 2 (1): 1-13. http://jurnal.unmuhjember.ac.id

/index.php/AGRIBEST/article/view/1369/110 5. [17 Juni 2020]. Roza K, Yulida, Yusri J. 2015. Analisis usahatani nenas di Desa Kualu Nenas Kecamatan Tambang Kabupaten Kampar. Jurnal Ilmiah Pertanian, 11 (2): 918.

https://journal.unilak.ac.id/index.php/jip/articl e/download/1261/855. [15 Mei 2020].

Silaban ESS, Ginting R, Jufri M. 2017. Analisis efisiensi produksi nanas (Ananas comusus $L$ (Merr)) (studi kasus : Desa Siabal-abal 2, Kecamatan Sipahutar, Kabupaten Tapanuli Utara). Jurnal Agribisnis, 8 (5). https://jurnal.usu.ac.id/index.php/ceress/article /view/19080/8059. [5 Mei 2020].

Sugiarto, Sunaryanto, dan Oetomo. 2003. Teknik Sampling. PT Gramedia Pustaka Utama. Jakarta.

Sumaryanto S, Wahida W, Siregar M. 2003. 
Jurnal Ilmu Ilmu Agribisnis: Journal of Agribusiness Science, 9(3), Agustus 2021

Estimasi tingkat efisiensi usahatani padi dengan fungsi produksi frontir stokastik. Jurnal Agro Ekonomi, $21 \quad$ (1). http://ejurnal.litbang.pertanian.go.id/index.ph p/jae/article/view/84844. [16 Mei 2020]. 